\title{
In Adam Smith's Own Words: The Role of Virtues in the Relationship Between Free Market Economies and Societal Flourishing, A Semantic Network Data-Mining Approach
}

\author{
Johan Graafland ${ }^{1} \cdot$ Thomas R. Wells $^{2}$
}

Received: 21 December 2019 / Accepted: 21 April 2020 / Published online: 29 April 2020

(c) The Author(s) 2020

\begin{abstract}
Among business ethicists, Adam Smith is widely viewed as the defender of an amoral if not anti-moral economics in which individuals' pursuit of their private self-interest is converted by an 'invisible hand' into shared economic prosperity. This is often justified by reference to a select few quotations from The Wealth of Nations. We use new empirical methods to investigate what Smith actually had to say, firstly about the relationship between free market institutions and individuals' moral virtues, and secondly about the further relationship between virtues and societal flourishing. We show with more quantitative precision than traditional scholarship that the invisible hand reading dramatically misrepresents both the nuance and the sum of Smith's analysis. Smith paid a great deal of attention to a flourishing society's dependence on virtues, including the non-self-regarding virtues of justice and benevolence, and he worried also about their fragility in the face of the changed incentives and social conditions of commercial society.
\end{abstract}

Keywords Adam smith $\cdot$ Doux-commerce $\cdot$ Societal flourishing $\cdot$ Self-destruction $\cdot$ Semantic network data-mining $\cdot$ Virtues

\section{Introduction}

Among business ethicists, Adam Smith is widely viewed as the defender of an amoral if not anti-moral 'greed is good' utilitarian school of economics in which the private selfinterested actions of individuals are translated by the invisible hand of the free market price mechanism into public prosperity. Despite a slew of scholarly research in the history of ideas that almost universally condemns this reading of Smith, it remains dominant in both business ethics scholarly literature (as analyzed by Hühn and Dierksmeier 2016) and textbooks (including recent ones like Crane and Matten 2016; Velasquez 2014). ${ }^{1}$

Johan Graafland

J.J.Graafland@uvt.nl

Thomas R. Wells

t.r.wells@hum.leidenuniv.nl

1 Tilburg School of Economics and Management, Tilburg University, Tilburg, The Netherlands

2 Institute for Philosophy, Leiden University, Leiden, The Netherlands
We believe that the misrepresentation of Smith's writings has had a pervasive and regrettable influence on business ethics, firstly by cutting off a variety of research pathways that a better reading would enable, and secondly by making weak arguments — such as that of Milton Friedman (1970) seem stronger than they are. Unfortunately, the misreading of Smith is somewhat self-sustaining, since the picture it presents of his ideas is so intellectually and morally unappealing that few business ethicists have been motivated to dig into the professional secondary literature or read him themselves. ${ }^{2}$

\footnotetext{
${ }^{1}$ In their textbook, for example, Andrew Crane and Dirk Matten, categorize Smith together with Milton Friedman as promoting the moral theory of 'egoism' (Crane and Matten 2016, 92). In his textbook, Manuel Velasquez not only outlines a Mandevillian reading of Smith, in which "Motivated only by self-interest, private businesses are led to serve society" (Velasquez 2014, 176), but even advances a criticism of this Smith:

Smith's analysis wrongly assumes that every human being is motivated only by a "natural" and self-interested desire for profit. Smith, at least in The Wealth of Nations, assumes that in all dealings a person "intends only his own gain." Human nature follows the rule of "economic rationality". (Velasquez 2014, 180-81).

2 Matthias Hühn and Claus Dierksmeier undertook a literature survey of how Smith is understood by academic business ethicists publishing in the Journal of Business Ethics and Business Ethics: A European Review (Hühn and Dierksmeier 2016). The overwhelming majority of
} 
Naturally there are exceptions to this-business ethicists such as Patricia Werhane $(1991,2000)$ and Matthias Hühn (2019) who have tried to bring a fuller, more accurate and sophisticated reading of Smith into business ethics. We aim to contribute to that effort of recovering the real Adam Smith for business ethics: the professor of moral philosophy who studied the classics and debated the ethics of the new commercial society with contemporaries like Rousseau, Hume, and Mandeville. We think that this Smith thought long and hard about the problems and promise of early commercial society and still has much to offer, especially in his subtle account of the moral virtues and their relationship to institutional settings and flourishing. There is great interest in virtue ethics among contemporary business ethicists, yet, as Ferrero and Sison's excellent overview notes (Ferrero and Sison 2014), this has so far been mostly limited to the Aristotelian tradition (whether via a classical reading of Aristotle or via the work of his most notable modern disciple, Alasdair MacIntyre (MacIntyre 1981)). Smith's position as a virtue ethicist observing the development of modern capitalism makes him a potentially valuable yet so far underused resource. $^{3}$

However, we do not want to bring merely one more historical reconstruction of Smith into the business ethics literature. Instead we seek to make a different kind of contribution by applying new digital research and visualization techniques to Smith's Wealth of Nations (1789). These techniques allow us to analyze what Smith meant by examining empirically (quantitatively) what he said. While traditional qualitative scholarship analyses what Smith meant by developing complicated holistic theories about his views that

\footnotetext{
Footnote 2 (continued)
}

the 150 papers they surveyed endorse the reading that "Adam Smith established and defended the proposition that the worlds of ethics and economics are unrelated and that, in effect, society fares best when allowing individual self-seeking to roam freely" (Hühn and Dierksmeier 2016, 119). Only 3 authors (2\%) clearly endorsed a version of Smith consistent with the professional history of ideas scholarship (Werhane 2000; Gray and Clarke 2005; Newbert 2003), and even they did not make much use of that deep secondary literature.

3 Although we do not think that Smith can offer guidance on all the business ethics challenges of our time, given the very different political system and the kind and size of business organizations that he was familiar with. We should be careful not to pose anachronistic questions to Smith (for example about the organization of the firm), or we will end up projecting our own answers onto him. Nor should we make the mistake of treating his works as scripture: if we find interesting ideas in Smith's work that we might make use of today, it must be because those ideas are interesting, not because they are Smith's. (See further Wells 2019). make the best sense of all his writings and their historical context, these quantitative methods use fine-grained analysis of his texts to ask 'how much' questions. For example, by counting Smith's references to non-self-interested virtues in the Wealth of Nations we can empirically test the claim that Smith was only concerned with the pursuit of self-interest in that book. Furthermore, we can go beyond giving a yes or no answer to indicate precisely how much attention he dedicated to one or the other. This approach is especially appropriate to Smith, since he chose his words with great care, and edited and revised both his published books multiple times (even at the expense of completing other planned works). As Smith put it in a letter to his publisher about the last revisions to his Theory of Moral Sentiments, "I am a slow a very slow workman, who do and undo everything I write at least a half a dozen of times before I can be tolerably pleased with it" (Smith 1987, p. 311 (1788)).

Our methods allow us to map Adam Smith's reasoning and concerns in a way that captures both detail and generality. They allow two specific kinds of contributions. First, as already mentioned, by counting up the frequency of Smith's references to various moral and economic concepts we can generate a more accurate picture of the distribution of Smith's attention. Second, we can draw out the relationships Smith analyzed between concepts, in particular the positive or negative relationship between free market institutions and individual virtues (or vices), and the positive or negative relationship between the virtues and societal flourishing (or its opposite). The 'Mandevillean' conception of the invisible hand-in which public benefits depend on private vices (Mandeville 1714) — features prominently in the 'greed is good' version of Smith's economics, justified by a handful of famous quotations from the Wealth of Nations, ${ }^{4}$ but how far are those quotations representative of Smith's analysis? These questions are important to understanding Smith's complicated views on the market; they may be particularly interesting to normative business ethicists making the case for personal ethics to managers and students; and they could not be asked without this new kind of method.

Besides the specific research questions we seek to answer in this paper, we believe this research makes three further

\footnotetext{
${ }^{4}$ Most notably "It is not from the benevolence of the butcher, the brewer, or the baker, that we expect our dinner, but from their regard to their own interest" (Smith 1789, I.ii.2), and Smith's (single) reference to the invisible hand in the Wealth of Nations "....by directing that industry in such a manner as its produce may be of the greatest value, he intends only his own gain, and he is in this, as in many other cases, led by an invisible hand to promote an end which was no part of his intention. Nor is it always the worse for the society that it was no part of it. By pursuing his own interest he frequently promotes that of the society more effectually than when he really intends to promote it. I have never known much good done by those who affected to trade for the public good. (Smith 1789, IV.ii.9)".
} 
contributions to the academic community of business ethics. First, we provide an alternative route to bringing the real Adam Smith into business ethics than the traditional route from close reading and the history of ideas literature. In the traditional route scholars present subtle exegetical arguments about what Smith really meant, but being persuaded of their reading depends upon having some prior familiarity with his texts. In our route, we present the evidence for our claims in the form of data, as one would present the results of an experiment. Anyone who follows our methodology can follow the reasoning of our interpretations (and dispute it) for themselves. We also provide data visualizations that accessibly summarize our results. Our hope is that this approach may pick up some readers missed by more traditional scholarly treatments of Smith, particularly those of our colleagues more used to empirical research methods. Second, we hope that demonstrating the value of these new digital empirical techniques to the scholarship of Adam Smith may contribute to a knitting together of an academic community presently somewhat divided between more normative philosophical and more empirical social scientific groupings. Sharing an interest in quantitative techniques creates more common ground and would allow us all to make greater use of each other's work. Third, the specific hypotheses that we test open up new research paths that others may wish to explore, such as concerning the reflexive relationship between market institutions and moral virtues.

The structure of this paper is as follows. In section II we link Smith to an enduring debate on the relationship between markets, virtues, and societal flourishing and elaborate our conceptual framework. In section III we explain the datamining methodology we used to gather the data for answering our research questions. In section IV we present the results of the empirical analysis, including visualizations of the relationships between several types of virtues (and their corresponding vices) and free market economies and societal flourishing. In the conclusion, we analyze our findings and explain what they add to traditional scholarship.

\section{Analyzing Smith's Rival Views on Markets, Virtues, and Flourishing: Conceptual Framework}

These days there is increased recognition even in mainstream academic economics that moral virtues contribute to the functioning of markets (Burbidge 2016; Abeler et al. 2019). But the reverse relationship—how virtues are affected by free market institutions-remains vigorously contested. In a seminal paper in the history of ideas Albert Hirschman distinguished rival views of how living in a market society influences moral values (Hirschman 1982). Beginning in the eighteenth century, a number of political economists had argued that market relations make people more cordial. Montesquieu for example claimed that "[...] wherever there is commerce, manners are gentle" (Cited in Hirschman 1982, p. 1464). Similarly, Adam Smith argued to his students that,

Whenever commerce is introduced into any country, probity and punctuality always accompany it..... Of all the nations in Europe, the Dutch, the most commercial, are the most faithfull to their word" (Smith 1760, p. 538 ; §326).

The underlying claim is that under the circumstances of a commercial society, certain values-such as honesty and fairness - and the people holding them, will be recognized and rewarded more than under a different social order, such as feudalism. Therefore, those values will flourish. Following Montesquieu's original French phrasing, Hirschman called this the 'doux-commerce' thesis. Doux-commerce continues to have modern defenders, including Richard Florida (2002), Deirdre McCloskey (2006), and Steven Pinker (2018). McCloskey, for example, argues that free markets nurture a long list of distinctly bourgeois virtues, including "enterprise, adaptability, imagination, optimism, integrity, prudence, thrift, trustworthiness, humor, affection, self-possession, consideration, responsibility, solicitude, decorum, patience, toleration, affability, peaceability, civility, neighborliness, obligingness, reputability, dependability, and impartiality" (McCloskey 2006, pp. 350-351).

In the same paper, however, Hirschman noted a rival thesis he termed 'self-destruction', which posits that the very success of capitalism creates the conditions for its own destruction and which began appearing in various forms in the nineteenth century among critics of capitalism such as Marx. Perhaps the most interesting version of the 'selfdestruction' thesis for our purposes is a mirror image of doux-commerce which, according to Hirschman (1982, p. 1466), was first articulated in its modern form by Fred Hirsch in "The Depleting Moral Legacy" of capitalism (Hirsch 1977). Here the claim is that the values required for success under capitalism-particularly the pursuit of individualistic self-interest - undermine the sustainability of the very virtues, such as fairness and honesty, that are required to keep such a complex social system working as it is supposed to. Hirsch argues that the social virtues underpinning the successful operation of markets and business organizations-such as "truth, trust, acceptance, restraint, obligation"- -are a legacy of the pre-capitalist and pre-industrial past, and especially of religion (Hirsch 1977, pp. 138-143). This legacy has diminished with time, due in part to the relentless emphasis on self-interest but also to the greater mobility and anonymity of commercial society. The danger is that once a large proportion of people come to think that it is legitimate to focus only on advancing their material self-interest, without considering what they ought to do for 
Fig. 1 Conceptual framework
I

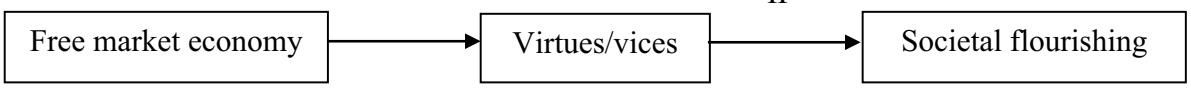

the sake of the common good, then all sorts of mutually beneficial cooperative projects become impossible, including capitalism itself. Without any moral compunction to hold us back, every citizen would strive to avoid paying taxes as far as they can; every employee would treat their 'colleagues' as competitors in a race for promotion; contracts would be kept only if convenient; judges would sell their decisions to the highest bidder; and so on.

As Hirschman noted, it is entirely possible-actually highly likely - for both doux-commerce and self-destruction mechanisms to operate at the same time. Thus, the really important question is not which mechanism is correct, but their net effect on moral values (Hirschman 1982, p. 1483): i.e., does a market society undermine its moral foundations faster than it builds them up?

This is where our interest in Adam Smith's writings comes in. For although Smith is generally considered a clear proponent of the doux-commerce thesis, scholars have noted that his books also include a number of remarks that demonstrate his understanding that market institutions can also have destructive effects. For example, he recognized that the high degree of division of labor permitted by the scale of production required to serve larger markets could rob workers of their moral and intellectual virtue (Smith 1789, V.i.3), ${ }^{5}$ and he worried about the risks that an unregulated finance sector posed to the "security of the whole society" via the intemperance of 'prodigals' and the imprudence of 'projectors' (Smith 1789, II.ii.94). Likewise Smith explicitly rejected Bernard Mandeville's 'hive' model in which a society's prosperity depends on the private vice (meaning unprincipled selfishness) of its members and would fail if too many took virtues like temperance, justice and honesty seriously (Smith 1790, VII.ii.4.6). Yet Smith also defends (a morally bounded version of) self-interest at many points in the Wealth of Nations, both as a right of individuals and for its tendency to generate economic benefits to society (Wells 2013). We do not mean to accuse Smith of holding incompatible views (as in the tiresome and long resolved 'Adam

\footnotetext{
5 Smith's remarks about the risk that the pin factory may produce 'pinheads' are worth including: "The man whose whole life is spent in performing a few simple operations... has no occasion to exert his understanding, or to exercise his invention in finding out expedients to removing difficulties...He, naturally loses, therefore, the habit of such exertion, and generally becomes as stupid and ignorant as it is possible for a human creature to become... incapable... of conceiving any generous, noble, or tender sentiment (Smith 1789, V.i.f.50)".
}

Smith problem', wherein he was accused of endorsing selfishness in his economics book and sympathy in his ethics book $^{6}$ ), but rather to dig down into the distinct mechanisms that Smith concerned himself with, as a resource for better understanding the challenges of a market society. ${ }^{7}$

Figure 1 presents an overview of the conceptual framework that underlies our analysis of Smith's views on the relationships between free market economy and virtues (I) and between virtues and societal flourishing (II). Below, we first define the three concepts distinguished in Fig. 1. Then we introduce four types of market societies that can be derived from combinations of the two relationships postulated in Fig. 1.

We define a free market economy in a way recognizable to both Smith and our readers. The organization of production and prices should be left to the free operation of competitive markets, including factor markets (labor, land, capital). The conditions for competition are relatively obvious and simple: freedom of entry (no closed guilds, mandatory apprenticeships, restrictions on labor movement, etc.); a considerable number of rivals (no de facto monopolies); and transparency about market opportunities (Blaug 1996, p. 42). The main economic task of the government is to ensure the working of the system as a whole, for example by protecting private property rights and enforcing contracts.

\footnotetext{
${ }^{6}$ For a succinct account of the scholarly deficiencies of 'the Adam Smith problem' see Raphael and Macfie's excellent introduction to the 1976 Glasgow edition of the Moral Sentiments (Smith 1790, 20-25).

7 We exclude Smith's other major work, the Theory of Moral Sentiments, and limit our study to the text of the Wealth of Nations for two main reasons. Firstly, for our purposes the Wealth of Nations is Smith's most interesting work because this is the book that inspires the Mandevillean 'greed is good' view of Smith so prevalent among business ethicists. The misunderstanding of Smith's ideas begins with the misunderstanding of what he wrote in the Wealth of Nations about the workings of commercial society and the conditions for its flourishing. Furthermore, we have a rhetorical as well as an investigatory aim for this paper. Since showing Smith talking about the non-self-interested virtues in the book he wrote directly about ethics would not be very surprising, it would be unlikely to change any minds. We think it is more powerful to show how central Smith considered the analysis of moral virtues even in his work directly about the economic domain of life. Finally, methodological reasons made it difficult to cover both texts adequately within the terms of our investigation. Although in principle one of the possibilities of these new quantitative methods is to allow a comparative analysis between an author's texts, the very different style, subject, and length of Smith's two books would have required us to create a more generic methodology with lower resolution for capturing Smith's analysis of the specific relationships to market conditions and collective prosperity that we were most interested to investigate.
} 
Fig. 2 Four types of market societies

\begin{tabular}{|c|c|c|}
\hline & $\begin{array}{l}\text { Free markets discourage } \\
\text { (encourage) virtues (vices) } \\
(\mathrm{I}<0)\end{array}$ & $\begin{array}{l}\text { Free markets encourage } \\
\text { (discourage) virtues (vices) } \\
(\mathrm{I}>0)\end{array}$ \\
\hline $\begin{array}{ll}\text { Virtues (Vices) } & \text { decrease } \\
\text { (increase) } & \text { societal } \\
\text { flourishing }(\mathrm{II}<0) & \end{array}$ & $\begin{array}{l}\text { (Mandeville's hive model) } \\
\text { Flourishing vicious market } \\
\text { society } \\
\text { I * II }>0\end{array}$ & $\begin{array}{l}\text { Stagnating virtuous market } \\
\text { society } \\
\text { I * II }<0\end{array}$ \\
\hline $\begin{array}{ll}\text { Virtues (vices) } & \text { increase } \\
\text { (decrease) } & \text { societal } \\
\text { flourishing (II }>0) & \end{array}$ & $\begin{array}{l}\text { Stagnating vicious market } \\
\text { society } \\
\text { I * II }<0\end{array}$ & $\begin{array}{l}\text { Flourishing virtuous market } \\
\text { society } \\
\text { I * II }>0\end{array}$ \\
\hline
\end{tabular}

Moral virtues are acquired, excellent character traits that are exhibited in a person's habitual behavior (Hursthouse and Pettigrove 2018). A virtue is different from following a rule or practical reasoning, For example, if we describe someone as honest we don't mean merely that they always behave honestly (e.g., they always tell the truth), nor that they believe that 'honesty is the best policy', but rather that, being honest, they find honesty appealing and good, and lying unappealing. Virtues are specific to particular domains of life. For example, honesty concerns mastery of the moral values of communication, going beyond mere truth telling (i.e., not lying) to sincerity and frankness. Many virtues are other-regarding (like honesty), but the general idea of a virtue is excellence in living, and some domains of living are more directly orientated to the self (while others have a more transcendent orientation, such as the traditional Christian virtues of hope and faith). Because virtues are character traits they are an intimate part of us: when we evaluate virtues we are evaluating what kind of person this is, or how good they are at being a person. ${ }^{8}$

We define societal flourishing again in a way recognizable to both Smith and contemporary readers, as the collective prosperity and welfare of a society. 'Collective' does not only refer to the aggregate amount of wealth in a society but also to how widely prosperity is shared among its members. Welfare can also go beyond narrow metrics of consumers' economic command to their emotional well-being and happiness.

\footnotetext{
${ }^{8}$ In the Moral Sentiments Smith elaborates this account of virtue ethics in various ways, such as the role of the moral imagination in each individual's moral development (See e.g., Broadie 2006; Raphael 2007; Hanley 2009). However, analyzing this would draw us too far from our concern with what Smith is saying about virtues in the Wealth of Nations.
}

Based on the relationships I and II, we distinguish four types of market societies (see Fig. 2). In the flourishing virtuous market society, the free market economy encourages virtues (discourages vices) $(I>0)$, whereas virtues increase (vices decrease) societal flourishing (II $>0 \rightarrow \mathrm{I} *$ II $>0$ ). In the stagnating vicious market society, free market economies allow the vices to reign $(I<0)$, and vices have a destructive effect on societal flourishing (II $>0 \rightarrow \mathrm{I} * \mathrm{II}<0$ ). In the flourishing vicious market society, the free market economy stimulates vices $(I<0)$, and vices stimulate societal flourishing (II $<0 \rightarrow \mathrm{I} * \mathrm{II}>0)$. (This is Mandeville's hive model.) Finally, in the stagnating virtuous market society, markets encourage the virtues ( $\mathrm{I}>0)$ but the virtues have a destructive effect on societal flourishing (II $<0 \rightarrow \mathrm{I} * \mathrm{II}<0$ ).

The main research questions of this paper are therefore:

1. To what extent did Adam Smith embrace the view that free markets encourage or discourage virtues?

2. To what extent did Smith believe that virtues increase or decrease societal flourishing?

3. What type of virtues do free markets encourage or discourage according to Smith?

4. What type of virtues increase or decrease societal flourishing according to Smith?

The answers to questions 1 and 2 provide insight into what type of market society Adam Smith expected: a flourishing vicious market; a flourishing virtuous market; a stagnating vicious market; or a stagnating virtuous market? The answers to questions 3 and 4 offer a finer grained view of Smith's analysis in the Wealth of Nations of how distinct virtues would fare and function in the relationship between free market economy and societal flourishing. 
Table 1 Search queries for virtues and vices

\begin{tabular}{ll}
\hline Categories & Search queries \\
\hline 1 Temperance & Virtues: Frugal/ity; parsimony/nious; sober/sobriety \\
& Vices: Prodigal/ity; drunkenness; vanity/vain; ostentation; debauchery; intemperance; avidity; rapacity; extravagant; profusion; \\
& avarice; anxious \\
& Virtues: Industrious; zeal/oulsly; diligent/ce; expedient/ious; ambitious/on \\
& Vices: sloth(ful); lazy; dissolute; idle(ness); indolent/ce \\
& Virtues: Prudent/ce; understanding; attentive/on; foresight/see; careful; vigilant; orderly; keen(ness); patient/ce \\
3 Prudence & Vices: Imprudent; rash/ness; ignorant/ce; stupid/ity; negligent/ce; disorderly; injudicious; careless; folly; levity; inattentive; \\
& shortsighted; capricious; prejudice \\
& Virtues: Just(ice); probity; faithful; fidelity; frank(ness); integrity \\
& Vices: Unjust/ice; cheating; deceptive/on; criminal; oppressive; infidelity; malversation; corruptive/ion \\
& Virtues: Benevolent/ce; liberal(ity); friendly/ship; fellowship; humane/ity; union; noble; serviceable; generous/ity; hospitable/ \\
& lity; gentle(ness); affectionate; charity; tender; caring \\
& Vices: Selfish/ness; insolent/ce; self-love; base; jealous/y; envy/ious; animosity; discord; narrowness; mean/ ness, invidious; \\
& infamous; savage; indignation; cruel; malice/ious/malignant; resentment; contemptuous \\
& Virtues: Courage; bold; perseverance; fortitude; adventurous \\
& Vices: Effeminacy; dastardliness; cowardice \\
\hline \multirow{2}{*}{ Courage } &
\end{tabular}

Table 2 Examples of concepts for free market economy and societal flourishing

\begin{tabular}{ll} 
Free market economy & $\begin{array}{l}\text { Free trade; (free) competition; (free) commerce; commercial society; exchange; rivalry/ship; private property; free } \\
\text { (independent) work man; labour (division); riches; regulation(-); privileges(-); monopoly(-); tax }(-) \text {; bounty(-) }\end{array}$ \\
Societal flourishing $^{\mathrm{a}}$ & $\begin{array}{l}\text { Great fortunes; prosperity; productivity; (public) opulence; real wealth; riches; business success; thriving nations; } \\
\text { improvement (of land); annual produce; capital; society's interest; societal flourishing; public(k) interest; (public(k)) } \\
\text { happiness; convenience of life; progress satisfaction; comfort; happiness; utility; health; security; bankruptcy (-); } \\
\text { ruin(-); famine (-); waste (-);deprivation (-); misery(-) }\end{array}$ \\
\hline
\end{tabular}

(-) indicates a negative indicator

\section{Methodology}

In order to answer these questions systematically, we adopted a semantic network approach (inspired by Alfano et al. 2018) for quantifying, mapping and analyzing the links between free market economy, virtues (vices) and societal flourishing in Smith's Wealth of Nations. In this approach, the prevalence of relationships between various concepts is identified by using data-mining techniques that count the number of passages in a publication that mention and link those concepts. This methodology also allows us to study the valence of these relationships, i.e., whether they are positive or negative. The more frequently a certain relationship shows up in Smith's writing, the more important (we assume) it was for Smith to communicate to his readers.

The question arises how big or small a passage should be. In the case of Smith's Wealth of Nations, a handy size is the numbered paragraph, which are the tightly knit units of Smith's thought and, conveniently, the standard unit of reference in the literature. The advantage of using paragraphs over using sentences is that they express more complex thoughts and arguments. For this purpose, we used a digital version of the standard Glasgow Edition that reports the paragraphs in a standardized way.

Before starting our digital research, we first performed a detailed scan of the text to identify the various terms that Smith uses to refer to the free market economy, virtues (vices) and societal flourishing. The virtues were grouped into six clusters (see Table 1). Clusters 1-3 concern virtues related to self-interest: prudence, temperance, and industriousness. Clusters 4-6 are virtues we categorize as non-selfregarding: justice, benevolence, and courage. For example, we grouped references to the 'minor' virtues of frugality, parsimony and sobriety and the minor vices of prodigality, vanity, and avarice within the larger cluster of 'temperance'. During our digital search process, we further updated this list if we discovered additional virtue terms. Examples of terms relating to free market economy and societal flourishing are listed in Table 2.

Each virtue or vice was operationalized with its word stem(s). Next, we entered all search queries to identify all passages in the Wealth of Nations which include at least one word that begins with the word stem of the virtue or vice. Each identified passage was fully read to analyze whether: (1) the word stem really refers to a virtue or vice (rather than to some other concept); (2) Smith describes a relationship 
between this virtue (vice) and a concept of market economy; (3) Smith perceives this relationship (of type I) to be positive or negative; (4) Smith describes a relationship between this virtue (vice) and a concept of societal flourishing; and (5) Smith perceives this relationship (of type II) to be positive or negative. If the passage did not describe or imply a relationship with market economy or societal flourishing, we dropped this passage.

The outcomes of this search process were dummy coded in a spreadsheet. We converted this spreadsheet with an open-source application into network visualizations and analyzed for each set of virtues the nature of their relationship with free market economy and with societal flourishing to answer the four research questions.

\section{Limitations of Our Methodology}

The quantitative methods we are trying to apply to Smith's texts are relatively new in the humanities. We want to emphasize that although they allow new and interesting kinds of questions to be asked, they are still in development and better thought of as a complement to than as a substitute for traditional exegesis. (Hence our own 'hybrid' methodology of hand-coding passages of interest before counting them.)

Our methods investigate frequency and correlations between concepts within paragraphs of Smith's text. Our claim that this is meaningful depends on assumptions. We assume that if Smith wrote more frequently about some concepts than others, this indicates that he considered them more important to his overall account. Likewise, Smith's paragraphs are tightly linked units of thought. We assume that this is the appropriate unit of analysis to capture Smith's analysis of relationships between concepts. We believe these assumptions are plausible enough to be worth building on, but we freely admit their limitations.

Here is one significant challenge to our first assumption. Smith wrote the Wealth of Nations for a specific audience (as 'relativistic' historians of ideas rightly emphasize). Thus, it is not just a presentation of his ideas but also a rhetorical device for communicating them. Consider how a teacher (Smith was also a teacher for many years) may spend much more time and words on some ideas than others, not because they are proportionately more important but because the teacher knows from experience that this class will find those ideas especially difficult to grasp and so they will require much more careful and elaborate explanation or even repetition. Hence, when we measure the choices Smith made about how frequently to analyze the relationships between virtues, free markets, and societal flourishing, we may be measuring not merely how important Smith thought they were to the coherence of his whole account, but also how easily he expected his readers to understand and go along with them. ${ }^{9}$

A different challenge concerns our focus on the paragraph as a unit of thought. Since Smith also thought in bigger and smaller units, this may lead us to undercount or overcount relationships. For example, a particularly complicated single relationship between a virtue and economic flourishing may have several components each analyzed by consecutive paragraphs, yet our system would count each paragraph in which such analysis occurred as a separate instance. We must make a further assumption that this methodological flaw is not biased in one direction or another.

\section{Results}

We collected 448 citations, as summarized in Table 3 and Fig. 3, that present an overview of the results. The visualizations in Fig. 3 were generated with Gephi 9.2. In Fig. 3, the red lines between free markets and the six categories of virtues indicate that free markets encourage (discourage) virtues (vices). The blue lines refer to a negative (positive) influence of free markets on virtues (vices). Similarly, the red (blue) lines between the six categories of virtues and societal flourishing indicate that virtues increase (decrease) societal flourishing or vices decrease (increase) societal flourishing. Line thickness represents the frequency of the positive and negative relationships.

As an example of the detailed relationships (that underlie the overviews in Fig. 3 and Table 3), Fig. 4 presents the results for one of the six categories (prudence). In this Figure, we distinguish the virtues (on the left) from the vices (on the right) that we categorized under the heading of prudence (imprudence). Again the red (blue) lines between free markets and the individual virtues indicate that free markets encourage (discourage) these virtues, whereas the red (blue) lines between free markets and the individual vices indicate that free markets discourage (encourage) these vices. The same holds for the relationships between the virtues (vices) and societal flourishing.

\section{Discussion and Conclusions}

We discuss the results by reference to our main research questions.

\footnotetext{
${ }^{9}$ For example, Smith dedicated perhaps a quarter of the Wealth of Nations to criticizing the mercantilist doctrine that dominated contemporary thought and policy advice. Does this represent how important he considered mercantilist theories of money and trade or rather the particular rhetorical demands of defeating an entrenched theory of political economy?
} 
Table 3 Outcomes

\begin{tabular}{lrrrrrrr}
\hline & Temperance & Industrious & Prudence & Justice & Benevolence & Courage & Total \\
\hline Relationship I: & Free market & operation-virtues/vices & & & & \\
I= positive & 23 & 27 & 31 & 18 & 19 & 2 & 120 \\
I=negative & 24 & 4 & 23 & 5 & 28 & 4 & 88 \\
& 47 & 31 & 54 & 23 & 47 & 6 & 208 \\
Relationship II: Virtues/vices- & societal flourishing & & & & \\
II= positive & 83 & 24 & 49 & 26 & 34 & 5 & 221 \\
II=negative & 4 & 2 & 5 & 1 & 6 & 1 & 19 \\
& 87 & 26 & 54 & 27 & 40 & 6 & 240 \\
\hline
\end{tabular}

Fig. 3 Markets, virtues, and societal flourishing: overview of results (Red lines (blue) lines indicate a positive (negative) relationship)

Fig. 4 Markets, virtues, and societal flourishing: prudence (Red lines (blue) lines indicate a positive (negative) relationship. Detailed figures for the other five categories are available from the authors)
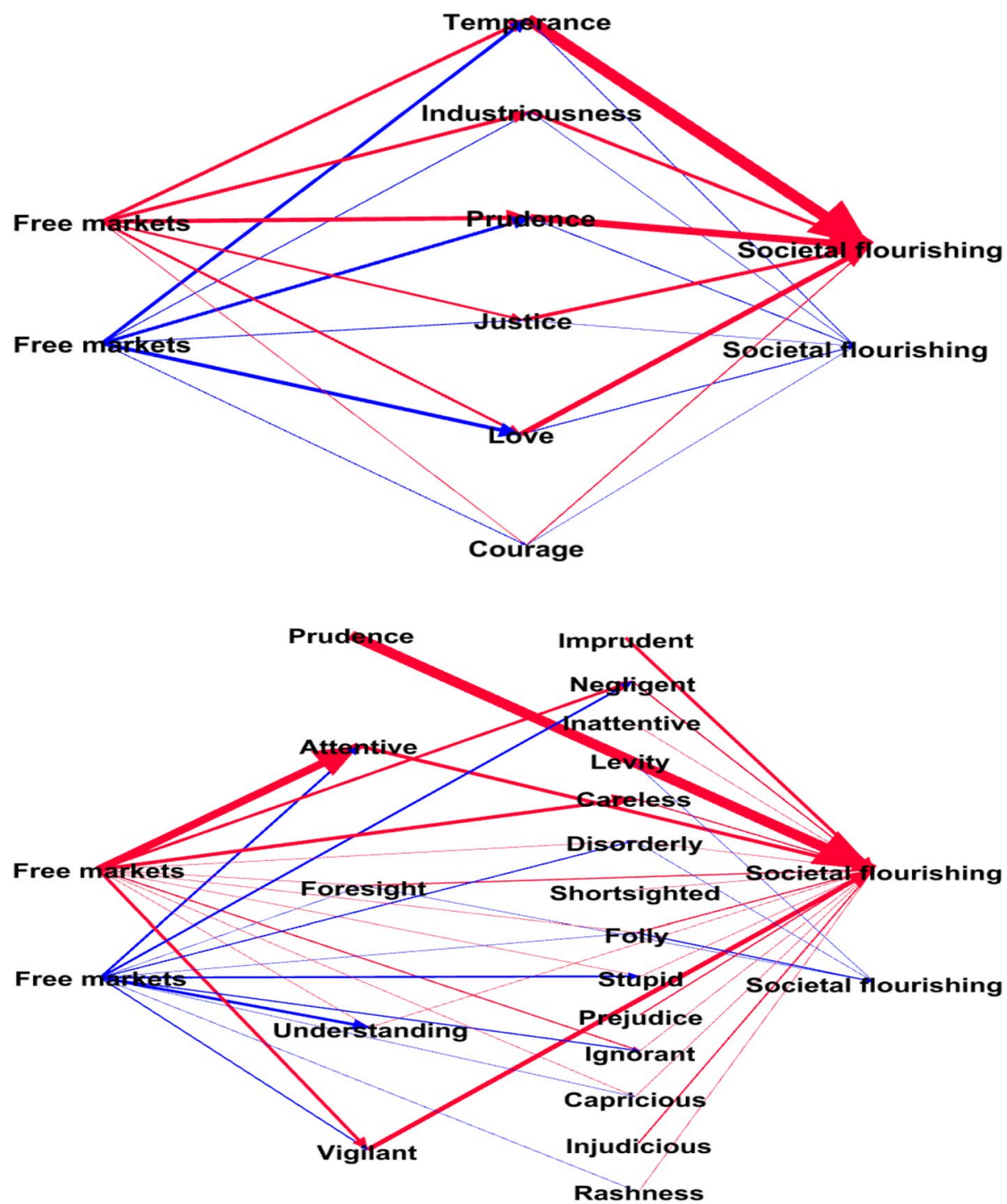

\section{To What Extent Did Adam Smith Embrace the View that Free Markets Encourage or Discourage Virtues?}

In the Wealth of Nations, Smith makes some 208 references to relationships between (non)free market conditions and virtues (vices). In the majority of cases (about 60\%) he associates free markets positively with virtues, and in $40 \%$ he associates free markets with vices. This ratio allows us to see very simply a point that numerous traditional scholars of Adam Smith have made at length, which is that Smith was no ideologue but a thoughtful and rigorous academic who paid very careful attention to the critiques of commercial 
society brought by his contemporaries like Rousseau even though his final conclusion was firmly in its favor (See e.g., Hanley 2008; Rasmussen 2008; Griswold 2010).

\section{To What Extent Did Smith Believe that Virtues Increase or Decrease Societal Flourishing?}

Smith makes a total of 240 references to virtues in relation to societal flourishing, of which the overwhelming majority (over 90\%) associate virtues positively with flourishing (or associate vices with societal failure). This contrasts directly and emphatically with the Mandevillean hive thesis that Smith is often presented as endorsing, wherein it is private vices like vanity, dishonesty, and selfishness that generate public prosperity. For example, Smith makes a mere 4 references to the idea that the vice of intemperance can drive public prosperity, 6 references to selfishness and unkindness driving prosperity (the vice that corresponds to the virtue of benevolence), and only 1 reference to injustice doing so.

Thus, while it is true that Smith made a few remarks consistent with Mandeville's hive thesis, including those famous ones always quoted, he had far more to say about the opposite thesis that societal flourishing relies on the presence of individual virtues. Having a figure as clear and dramatic as $90 \%$ to back up this point may help in finally uprooting the invisible hand reading of Smith from among the business ethics community and elsewhere. Instead of writing off Smith as a defender of egoism, business ethicists may be curious to read about the other $90 \%$ of what Smith had to say about how virtues matter to a flourishing economy.

\section{What Type of Virtues Do Free Markets Encourage or Discourage?}

It is interesting to look separately at the self-regarding (temperance, prudence, and industriousness) and other-regarding virtues (justice, benevolence, and courage). Within each category as a whole, Smith refers more frequently to virtues in relation to free market conditions than to vices. Nevertheless there are interesting differences within each category that illustrate the nuance of Smith's analysis.

Free market conditions appear much more frequently associated with (the cluster of virtues of) industriousness than with its corresponding vices (by a ratio of 6.5). This one-sided ratio may not be surprising in the context Smith was writing in, in which the diligent work ethic induced by the spread of market institutions, through more vigorous, fair, and well-compensated competitive opportunities for success, contrasted dramatically with the cronyism and complacency of the rentier economy it was coming to displace.

However, the ratio of prudence to imprudence is merely 1.3 and the ratio for temperance to intemperance is almost 1 to 1 . This suggests Smith considered the relationships of the other two self-regarding virtues with free market conditions to be more complicated, with multiple possible positive and negative mechanisms to be considered. This is consistent with recent commentary on how Smith's virtues respond to the economic incentives and opportunities of commercial society (Wells and Graafland 2012) from which we borrow below.

Smith understood the virtue of prudence as the command of one's self-interest: its proper understanding, discipline, and security. That includes a good deal of critical self-reflection to determine what one's intermediate goals and interests should best be. The busyness of commercial society can be a school for teaching this epistemic humility and discipline, but there are also ways in which its fast-moving pace as well as the wealth that it creates can distract us.

Smith defined temperance as the mastery of the all too human "love of ease, of pleasure, of applause, and other selfish gratifications" (Smith 1790, VI.iii.2) within the bounds of grace and propriety. It is especially vulnerable to the sudden abundance of consumption choices and the relative anonymity of commercial society. Rousseau's influential critique of the ethical character of commercial society was particularly founded on its vulnerability to the vice of vanity, which could feed off itself and generate an ethic of competitive conspicuous consumption (Rousseau 1754). It is not surprising that Smith would take the trouble to analyze such challenges, which would have been familiar to many of his readers.

Smith also refers with some frequency to the influence of free market conditions on the non-self-regarding virtues of justice and benevolence. (As our table of results shows, courage seemed of little interest to Smith, at least in so far as it related to free markets or flourishing, and so we won't discuss it further.) Again, there is a big difference for each virtue cluster in the ratio of references to virtues and vices.

Justice receives an impressive ratio of 3.6, suggesting that Smith found a great deal more ways to analyze the positive relationships between free markets and justice than with injustice. This makes sense in the context of a transformation from an informal relational economy managed by customary norms to a formal economy of written property rights and contracts between relative strangers. The virtue of justice for Smith concerns governing our actions affecting others according to a "sacred regard" for the general rules of natural jurisprudence. Although mostly a negative duty consisting in perfect compliance with fixed rules, it also carries with it a foundational commitment to equality and impartiality that seems well fitted to the ideal of commercial society (for example and in line with Hirsch's concern, by ruling out the "violation of fair play" in the "race for wealth, and honours, and preferments" (Smith 1790, II.ii.2.1). One may also note that Smith's interest in the latter aspect of justice is 
in line with the reading of him as no mere utilitarian calculator of efficiency, but a passionate critic of the unfairness of the crony mercantilism of his day.

In contrast, benevolence stands out for its negative ratio of 0.7 , meaning that Smith refers much more frequently to the relationship between free market conditions and the vice of unkindness and selfishness than to the virtue of kindness and caring about others. In contrast to justice, Smith's conception of benevolence consists of the non-juridicable, loosely defined, and contingent ('imperfect') positive moral responsibilities one has towards others, depending on one's relationship to them. (It is thus distinct from the indiscriminate care for all recommended by utilitarianism (FormanBarzilai 2010).) Smith's frequent references to the various ways in which market conditions might undermine this (such as through the increased anonymity of city life) suggests he worried a lot about this issue.

\section{What Type of Virtues Increase or Decrease Societal Flourishing?}

This was the ranking of references to virtues increasing flourishing by relative frequency: temperance (83), prudence (49), benevolence (34), justice (26), industriousness (24), courage (5). If we assume that how frequently Smith analyzed their positive relationship with societal flourishing indicates their relative importance to his overall account, then this ranking contains some surprises.

Smith seems to have considered temperance especially significant for the achievement of societal flourishing. Another way of putting this is that he worried a lot about the dependence of the functioning of a 'system of natural liberty' on individuals' mastery of their selfish appetites. Recall also that Smith worried about the many ways that free market conditions could produce intemperance.

Another surprise is the high ranking of benevolence, well above justice. Smith is often said to have supported commercial society on the grounds that a transactional society does not depend on our limited interest in and capacity for caring about and attending to others. (For example, "I share Adam Smith's skepticism about the benefits that can be expected from 'those who affected to trade for the public good"" (Friedman 1970).) This result suggests that Smith found much more use and importance for benevolence in his system than is commonly appreciated. The fact that Smith makes so many references to the relationship between prosperity and the virtue of kindness and care for others (and nearly 6 times as many as to its relationship with the vice of selfishness) gives us further confidence to dismiss the egoistic 'greed is good' reading of Smith, and also to dismiss the persistent claim that the Wealth of Nations analyses the economy as a collection of atomistic individuals relating merely by contract (i.e., in which the only social virtue would be commutative justice).

A final surprise is the relative low ranking of industriousness. Apparently Smith did not have all that much to say about how the prosperity of a commercial society related to the industriousness of its members. This appears to conflict with at least one influential recent account of the ethical basis of capitalism's success. Deirdre McCloskey has argued with particular reference to Smith that "the honoring of work apart from manual drudgery or heroic daring" is key to the self-identity of the bourgeoisie, the social class that both creates and arises out of modern commercial society (McCloskey 2006, p. 75). Perhaps Smith's place in such stories should be reconsidered.

\section{Doux Commerce or Self-destruction?}

Let us bring our analysis together now by way of examining what light it may shed on Hirschman's challenge by connecting our two mechanisms together to see how, according to Smith, the introduction of free market conditions affects societal flourishing via the virtues and vices it induces (Fig. 5).

The first thing to note is that the significance of both the doux-commerce and self-destruction mechanisms is supported by the extent to which Smith seems to have considered societal flourishing to depend on both the self and non-self-regarding virtues of the individuals in that society (relationship II). Therefore the key to deciding which is stronger is to look at the mechanisms by which virtues are induced or reduced by free market conditions (relationship I). At the aggregate level, adding up Smith's references suggests he found many ways to analyze both effects, but more frequently referred to positive (doux-commerce) than negative relationships (self-destruction). Yet at the micro-level,

Fig. 5 Updated conceptual framework

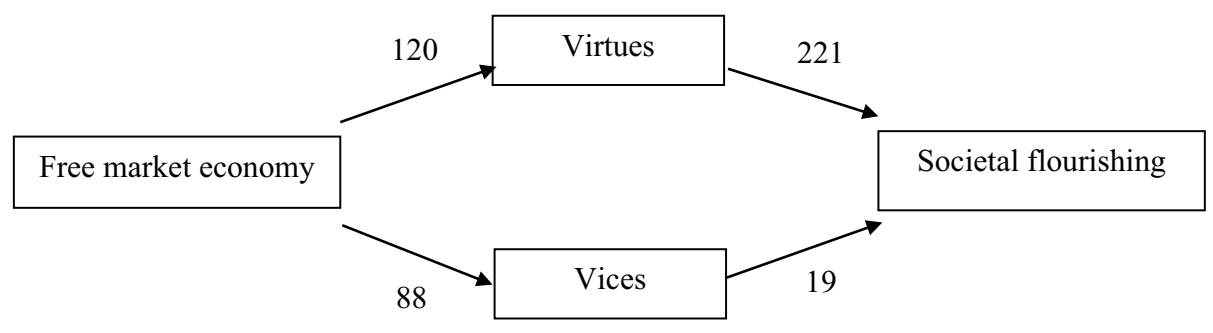


Smith seemed to be particularly concerned about the vulnerability of the two virtues of temperance and benevolence under free market conditions. This is something little remarked on in the traditional Smith scholarship, but is particularly visible using our quantitative methods. A commercial society is a collection of self-interested individuals but they need to be more than that if it is to flourish. It would be interesting to focus more closely on the problems Smith identified here (and perhaps also his solutions) as a way of making Hirschman's challenge and the debate that he inspired more precise. This is an example of the kind of interesting new research project that can derive from applying these new digital humanities methods even in the context of established debates.

Acknowledgements The authors thank Mark Alfano for advice and inspiration in the use of these new quantitative methods, and also Jordan Bellor and Ryan Hanley for their comments on an earlier version of this paper. This work was supported by the Templeton World Charity Foundation, Inc. Templeton World Charity Foundation had no involvement in the study design; collection, analysis and interpretation of data; in the writing of the report; and in the decision to submit the article for publication.

\section{Compliance with Ethical Standards}

Ethical Approval This article does not contain any studies with human participants or animals performed by any of the authors.

Open Access This article is licensed under a Creative Commons Attribution 4.0 International License, which permits use, sharing, adaptation, distribution and reproduction in any medium or format, as long as you give appropriate credit to the original author(s) and the source, provide a link to the Creative Commons licence, and indicate if changes were made. The images or other third party material in this article are included in the article's Creative Commons licence, unless indicated otherwise in a credit line to the material. If material is not included in the article's Creative Commons licence and your intended use is not permitted by statutory regulation or exceeds the permitted use, you will need to obtain permission directly from the copyright holder. To view a copy of this licence, visit http://creativecommons.org/licenses/by/4.0/.

\section{References}

Abeler, J., Nosenzo, D., \& Raymond, C. (2019). Preferences for truthtelling. Econometrica, 87(4), 1115-1153. https://doi.org/10.3982/ ECTA14673.

Alfano, M., Higgins, A., \& Levernier, J. (2018). Identifying virtues and values through obituary data-mining. The Journal of Value Inquiry, 52(1), 59-79. https://doi.org/10.1007/s1079 0-017-9602-0.

Blaug, M. (1996). Economic theory in retrospect (6th Ed.). New York: Cambridge University Press.

Broadie, A. (2006). Sympathy and the impartial spectator. In K. Haakonssen (Ed.), The Cambridge companion to Adam Smith (pp. 158-188). Cambridge: Cambridge University Press.

Burbidge, D. (2016). Space for virtue in the economics of Kenneth J. Arrow, Amartya Sen and Elinor Ostrom. Journal of Economic
Methodology, 23(4), 396-412. https://doi.org/10.1080/13501 78X.2016.1157201.

Crane, A., \& Matten, D. (2016). Business ethics: Managing corporate citizenship and sustainability in the age of globalization (4th ed.). New York: Oxford University Press.

Ferrero, I., \& Sison, A. J. G. (2014). A Quantitative analysis of authors, schools and themes in virtue ethics articles in Business Ethics and Management Journals (1980-2011). Business Ethics: A European Review, 23(4), 375-400. https://doi.org/10.1111/beer.12057.

Florida, R. L. (2002). The Rise of the Creative Class: And How It's Transforming Work, Leisure, Community, and Everyday Life. New York: Basic Books.

Forman-Barzilai, F. (2010). Adam Smith and the circles of sympathy: Cosmopolitanism and moral theory. Cambridge: Cambridge University Press.

Friedman, M. (1970). The social responsibility of business is to increase its profits. New York: The New York Times Magazine.

Gray, D., \& Clarke, P. (2005). Meeting Goodpaster's challenge: A Smithian approach to Goodpaster's paradox. Business Ethics: A European Review, 14(2), 119-126. https://doi.org/10.111 1/j.1467-8608.2005.00396.x.

Griswold, C. L. (2010). Smith and Rousseau in dialogue: Sympathy, Pitié, spectatorship and narrative. In C. L. Griswold (Ed.), Essays on the philosophy of Adam Smith. London: Routledge.

Hanley, R. (2008). Commerce and corruption: Rousseau's diagnosis and Adam Smith's Cure. European Journal of Political Theory, 7(2), 137-158. https://doi.org/10.1177/1474885107086445.

Hanley, R. (2009). Adam Smith and the character of virtue. New York: Cambridge University Press.

Hirsch, F. (1977). Social limits to growth. London: Taylor \& Francis.

Hirschman, A. O. (1982). Rival interpretations of market society: Civilizing, destructive, or feeble? Journal of Economic Literature, 20(4), 1463-1484.

Hühn, M. P. (2019). Adam Smith's philosophy of science: Economics as moral imagination. Journal of Business Ethics, 155(1), 1-15. https://doi.org/10.1007/s10551-017-3548-9.

Hühn, M. P., \& Dierksmeier, C. (2016). Will the Real A. Smith please stand up! Journal of Business Ethics, 136(1), 119-132. https:// doi.org/10.1007/s10551-014-2506-z.

Hursthouse, R., \& Pettigrove, G. (2018). Virtue ethics. In E. N. Zalta (ed.), The stanford encyclopedia of philosophy. Winter 2018. Metaphysics Research Lab, Stanford University. Retrieved from https://plato.stanford.edu/archives/win2018/entries/ethics-virtue/.

MacIntyre, A. C. (1981). After virtue. London: Duckworth.

Mandeville, B. (1997 [1714]). The fable of the bees. In E. J. Hundert (Ed.), The fable of the bees: And other writings. Indianapolis: Hackett Publishing.

McCloskey, D. N. (2006). The Bourgeois virtues. Chicago: University of Chicago Press.

Newbert, S. L. (2003). Realizing the spirit and impact of Adam Smith's capitalism through entrepreneurship. Journal of Business Ethics, 46(3), 251-258. https://doi.org/10.1023/A:1025564030922.

Pinker, S. (2018). Enlightenment now: The case for reason, science, humanism, and progress. New York: Viking.

Raphael, D. D. (2007). The impartial spectator: Adam Smith's moral philosophy. Oxford: Oxford University Press.

Rasmussen, D. C. (2008). The problems and promise of commercial society. Pennsylvania: Penn State Press.

Rousseau, J.-J. (1984 [1754]). Discourse on inequality. Translated by Maurice Cranston. London: Penguin.

Smith, A. (1978 [1760s]). Lectures on Jurisprudence (LJ). Edited by Ronald L. Meek, David Daiches Raphael, and Peter Stein. Indianapolis: Liberty Fund.

Smith, A. (1981 [1789]). An Inquiry into the Nature and Causes of the Wealth of Nations $(W N)$. Edited by Campbell, R. H., Skinner, A. S., and Todd, W. B. Indianapolis: Liberty Fund. 
Smith, A. (1982 [1790]). The Theory of Moral Sentiments (TMS). Edited by David Daiches Raphael and A. L. Macfie. Indianapolis: Liberty Fund.

Smith, A. (1987). The correspondence of Adam Smith. Indianapolis: Liberty Fund.

Velasquez, M. (2014). Business ethics: Concepts and cases (7th ed.). London: Pearson.

Wells T. R. (2013). Adam Smith on morality and self-interest. In C. Luetge (Ed.), Handbook of the philosophical foundations of business ethics (pp. 281-296). Springer. https://doi. org/10.1007/978-94-007-1494-6_26.

Wells, T. R. (2019). What Adam Smith really thought should not matter. Business Ethics Journal Review. https://doi.org/10.12747/ bejr2019.07.07.

Wells, T. R., \& Graafland, J. J. (2012). Adam Smith's bourgeois virtues in competition. Business Ethics Quarterly. https://doi. org/10.5840/beq201222222.
Werhane, P. H. (1991). Adam Smith and his legacy for modern capitalism. Oxford: Oxford University Press.

Werhane, P. H. (2000). Business ethics and the origins of contemporary capitalism: Economics and ethics in the work of Adam Smith and Herbert Spencer. Journal of Business Ethics, 24(3), 185-198. https://doi.org/10.1023/A:1005937623890.

Publisher's Note Springer Nature remains neutral with regard to jurisdictional claims in published maps and institutional affiliations. 